Georgetown University Law Center

Scholarship @ GEORGETOWN LAW

2018

\title{
Treaty Self-Execution as “Foreign” Foreign Relations Law?
}

Duncan B. Hollis

Temple University Law School, duncan.hollis@temple.edu

Carlos Manuel Vázquez

Georgetown University Law Center, vazquez@law.georgetown.edu

This paper can be downloaded free of charge from:

https://scholarship.law.georgetown.edu/facpub/2077

https://ssrn.com/abstract=3212910

Forthcoming in The Oxford Handbook of Comparative Foreign Relations Law (Curtis A. Bradley ed., Oxford University Press)

This open-access article is brought to you by the Georgetown Law Library. Posted with permission of the author. Follow this and additional works at: https://scholarship.law.georgetown.edu/facpub

Part of the International Law Commons 


\title{
CHAPTER
}

\section{TREATY SELF-EXECUTION AS "FOREIGN" FOREIGN RELATIONS LAW?}

\author{
DUNCAN B. HOLLIS AND \\ CARLOS M. VÁZQUEZ
}

In this chapter, we posit that in some cases a state's approach to a foreign relations problem may have an external origin, generating what might be called "foreign" foreign relations law" (FFRL). Differentiating the exogenous/endogenous origins of foreign relations laws raises questions that can deepen and develop the nascent field of comparative foreign relations law. ${ }^{1}$ Why do states accept (or reject) FFRL? How does FFRL enter a state's system? Who is doing the transporting? What happens to FFRL in its new site(s) - i.e., how static or dynamic does the concept prove in different settings? The answers to these questions may, in turn, set the table for more normative questions such as when states should seek (or resist) the importation of foreign relations law.

To illustrate the possibilities of FFRL, this chapter offers a case study of treaty self-execution. In Part I, we explain the doctrine's origins and its various manifestations in the United States and other national legal systems. We highlight some similarities between the forms the doctrine has taken in the United States and other states, including indications that the doctrine's origins and development in the latter states were influenced by U.S. case-law and scholarship. In Part II, we introduce three sets of framing questions regarding the identification, causation, and evolution of FFRL. We conclude by highlighting several practical and normative implications of FFRL.

\section{Self-EXeCUTION Through A COMPARATIVE LenS}

The doctrine distinguishing self-executing from non-self-executing treaties originated in the United States, and it is fair to say that few doctrines of U.S. foreign relations law have confounded U.S. courts and commentators as thoroughly. ${ }^{2}$ It is

1 A similar line of research already exists in many other areas of comparative law. See, e.g., Comparative International Law (Anthea Roberts et al. eds., 2018); Sujit ChOudhry, The Migration of Constitutional Ideas 16 (2006); Mark Tushnet, The Possibilities of Comparative Constitutional Law, 108 Yale L. J. 1225, 1229 (1999) Alan WATson, Legal Transplants - An ApProACH TO COMPARATIVE LAW (2d ed. 1993). But see Pierre Legrand, The Impossibility of 'Legal Transplants,' 4 MASTRICHT J. EURO. \& COMP. L. 111 (1997).

${ }^{2}$ See United States v. Postal, 589 F.2d 862, 876 (5th Cir. 1979). 
therefore surprising that this distinction has been embraced in other states. It has, for example, found its way into the South African Constitution, where scholars have noted that this "unwise[]" importation from U.S. jurisprudence 3 is "bound to create problems." In some states, the term "direct effect" is used to describe the selfexecution concept, but scholars appear to use the terms interchangeably. ${ }^{5}$

Commentators have argued that the U.S. term "self-executing" masks a number of distinct issues that should be addressed separately. ${ }^{6}$ Some have gone so far as to claim that "[t]his word 'self-executing' is essentially meaningless and the quicker we drop it from our vocabulary the better for clarity and understanding." 7 Nonetheless, the adoption of the concept - and the term - by other states suggests that it serves a purpose that courts (and sometimes constitution-writers) regard as necessary. A comparative look at the doctrine of self-execution of treaties reveals, moreover, that the term has been as versatile outside the United States as inside it.

\section{The U.S. Doctrine}

In U.S. case law, the distinction between self-executing and non-selfexecuting treaties articulates a limit on the judicial power to enforce treaties notwithstanding a general constitutional rule that treaties have the force of domestic law. That rule marked a shift from the constitutional law of Great Britain where treaties have never had the force of domestic law. U.K. courts only apply treaties if they have been given domestic legal force by statute. The U.S. Constitution, in contrast, declares that "all Treaties made, or which shall be made, under the Authority of the United States, shall be the supreme Law of the Land; and the judges in every State shall be bound thereby, any Thing in the Constitution or Laws of any State to the Contrary notwithstanding."

${ }^{3}$ Neville Botha, Treaty Making in South Africa: A Reassessment, 25 SAYIL 69, 91 (2000).

${ }^{4}$ John Dugard, International Law: A South African Perspective 62 (3d ed. 2005). Other scholars are less concerned. See Elias M. Ngolele, The Content of Self-Execution and Its Limited Effect in South African Law, 31 SAYIL 141 (2006); M.E. Olivier, Exploring the Doctrine of Self-Execution as Enforcement Mechanism of International Obligations, 27 SAYIL 99 (2002).

${ }^{5}$ See, e.g., Christina Binder \& Catherine M. Brölmann, The Law of Treaties Before Domestic Courts and Human Rights Bodies, in InTERnational LaW In Domestic CourTs (A. Reinisch and R. Janik eds., OUP, forthcoming 2018) (using the term 'selfexecuting' interchangeably with 'directly applicable' or 'directly effective'); Andre Nollkaemper, The Duality of Direct Effect of International Law, 25 EUR. J. INT'L L. 105, 106 n.3 (2014) (referencing Jean-Marie Henckaerts, Self-Executing Treaties and the Impact of International Law on National Legal Systems: A Research Guide, 26 InT’L J. Legal INFO. 56 (1998)).

${ }^{6}$ See, e.g., Carlos Manuel Vázquez, The Four Doctrines of Self-Executing Treaties, 89 AM. J. INT’L L. 695, 695 (1996).

${ }^{7}$ See, e.g., Myres S. McDougal, Remarks at the Annual Meeting of the American Society of International Law (April 27, 1951), 45 PROC. AM. SOC'Y INT'L L. 101, 102 (1951).

${ }^{8}$ U.S. CONST. art. VI. 
The concept of a non-self-executing treaty first emerged (even though the Court did not use the term) in Foster v. Nielson. ${ }^{9}$ In Foster, the U.S. Supreme Court recognized that some treaties require legislative implementation before they may be enforced by the courts despite the Constitution's declaration that all treaties have the force of domestic law. As the Court put it in Percheman v. United States, the paradigmatic non-self-executing treaty is one that "stipulates for a future legislative act." 10 Thus, if a treaty text says its aims are to be accomplished through subsequent legislation, then the courts may not enforce it until such legislation is enacted.

After Percheman, the Supreme Court did not address the self-execution doctrine again in any depth until 2008. In the interim, the Court routinely enforced treaties without pausing to consider whether they were self-executing. After the Second World War, U.S. lower courts invigorated the distinction between selfexecuting and non-self-executing treaties. ${ }^{11}$ But rather than confine the concept to treaties that expressly "stipulate for" future legislation, the courts inferred the need for implementing legislation from various factors. The resulting case law has been aptly described as confounding, and the Supreme Court's 2008 decision in Medellin v. Texas did little to clarify matters. ${ }^{12}$ U.S. courts have employed the non-selfexecuting concept to describe at least four reasons for why particular treaties might not be judicially enforceable despite the Constitution assigning them the force of domestic law.

First, some U.S. cases indicate that a treaty requires implementing legislation if it purports to accomplish something that, under the U.S. Constitution, can only be accomplished by statute. Examples include treaties that purport to raise revenue, make conduct criminal, or appropriate money. ${ }^{13}$ The Restatement (Fourth) of the Foreign Relations Law of the United States (hereinafter "Fourth Restatement") recognizes this as a distinct category of non-self-executing treaties. ${ }^{14}$

Second, numerous U.S. cases apply the distinction between self-executing and non-self-executing treaties to distinguish between treaty provisions that give private parties a cause of action and those that do not. ${ }^{15}$ The Third and Fourth Restatements take the position that the existence of a private cause of action is

${ }^{9}$ Foster v. Nielson, 27 U.S. (2 Pet.) 253, 314 (1829). The Court first used the term "selfexecuting" in Bartram v. Robertson, 122 U.S. 116, 120 (1887).

${ }^{10}$ United States v. Percheman, 32 U.S. (7 Pet.) 51, 89 (1833).

11 For analysis of these developments, see DAVID L. Sloss, The DeAth of Treaty Supremacy: An InVisible Constitutional Change (2016).

12 Medellín v. Texas, 552 U.S. 491 (2008). On Medellín, see generally Carlos Manuel Vázquez, Treaties as Law of the Land: The Supremacy Clause and the Judicial Enforcement of Treaties, 122 HARV. L. REV. 599 (2008).

${ }^{13}$ For citations, see Vázquez, supra note 6, at 718 \& nn.107-09.

14 Restatement (Fourth) of the Foreign Relations Law of the United States $\S$ 110 (3) cmt. f \& reporters' note 11 (AM. LAW INST. 2018) [hereinafter RESTATEMENT (FoURTH)].

15 See Vázquez, supra note 6, at 719-22. 
distinct from the "self-execution" issue. ${ }^{16}$ For present purposes, however, the important points are that (a) that U.S. courts have often referred to this as a "selfexecution" issue, and (b) that this issue is conceptually distinct from the others that the courts use the term "self-executing" to describe.

A third category derives from the cases that originally introduced the distinction between self-executing and non-self-executing treaties, i.e., a nonself-executing treaty is one that must be implemented by legislation because it "stipulates for some future legislative act." This does not mean that a treaty's selfexecuting character is a matter of international law rather than U.S. foreign relations law. Treaties generally do not address the manner in which they are to be enforced in the courts of states-parties, and it is clear that a treaty's self-executing character does not turn on whether the treaty requires direct judicial enforcement as a matter of international law. ${ }^{17}$ Still, this domestic law distinction turns on the type of substantive obligation to which the parties agreed. In the words of Chief Justice Marshall in Foster, did the parties "pledge the faith" of the nation to accomplish certain aims through subsequent acts of domestic legislation, or, in his words in Percheman, did they "stipulate for a future legislative act"? According to the Fourth Restatement, "[a] treaty provision is more likely to be regarded as selfexecuting if it imposes obligations or creates authorities designed to have immediate effects, as opposed to contemplating additional legal measures."18

Finally, U.S. courts have recognized that treaty provisions require legislative implementation before they may be judicially enforced if they are framed in vague or aspirational terms. This category also encompasses precatory terms (i.e., requiring parties to use their "best efforts"). The Fourth Restatement recognizes that "whether a treaty provision is sufficiently precise or obligatory" is a "consideration" in determining if it is self-executing, but does not treat this as a separate category of non-self-execution. ${ }^{19}$

Vague or aspirational treaty provisions might be unenforceable because such language suggests that the parties contemplated the provision's aims would be fleshed out through subsequent legislation. If so, then thus category might be regarded as a subset of the self-execution category recognized in Foster and Percheman (with stipulations for legislation inferred from-rather than expressed in-treaty text). Alternatively, these cases might reflect separation-of-powers concerns: to the extent a treaty provision leaves the parties with discretion on its

${ }^{16}$ See Restatement (Fourth) $\S 110 \mathrm{cmt} . \mathrm{b}, \S 111, \S 111 \mathrm{cmt}$ a; RESTATEMENT (THIRD) OF THE FOREIGN RELATIONS LAW OF THE UNITED STATES $\S 111 \mathrm{cmt} . \mathrm{h}$.

${ }^{17}$ See Vázquez, supra note 12, at 652-56. Accord ReStatement (Fourth) $§ 110 \mathrm{cmt}$. c.; Cf. Medellín, 552 U.S. at 546-61 (Breyer, J., dissenting) ("whether further legislative action is required before a treaty provision takes domestic effect ... is often a matter of how that Nation's domestic law regards the provision's legal status. And that domestic status-determining law differs markedly from one nation to another").

${ }^{19} I d ., \S 110, \mathrm{cmt} . \mathrm{d}$. 
performance, the political branches - not the courts - are best suited to exercise that discretion. Under this alternative explanation, implementing legislation is required-not because of the parties' intentions-but due to constitutional principles allocating power between U.S. courts and the political branches.

We think the second explanation is more persuasive. Even treaties that "stipulate for a future legislative act" do not, technically, reflect the parties' preference that the treaty be unenforceable pending enactment of legislation. Such language may reflect permission for states-parties not to apply the treaty as domestic law before further legislation is enacted. But, even treaties phrased in precise and obligatory terms implicitly permit parties to enforce such provisions in the courts via implementing legislation. Otherwise, states following the British rule would not be able to become parties.

\section{Self-Execution Across the Globe}

Looking at other states shows that (a) some have specifically imported selfexception in name or concept; (b) each of the foregoing U.S. types of non-selfexecution has an analogue in one or more other states; and (c) virtually all states recognize some version of the distinction between self-executing and non-selfexecuting treaties. Moreover, even though the term is susceptible to multiple meanings, most states employing it fail to draw clear distinctions among the possible grounds of non-self-execution.

\section{Constitutional Non-Self-Execution}

Although the British constitutional rule-where treaties may not be judicially enforced absent implementing legislation-pre-dates the U.S. selfexecution concept, courts and commentators outside the United States commonly use the term "non-self-executing" to describe the status of treaties in states that follow the British rule. Thus, "according to the government of India, treaties are not self-executing and therefore 'require enabling legislation, or constitutional and legal amendments in cases where existing provisions of law and the Constitution are not in consonance with the obligations arising from the treaty." ${ }^{20}$ In such strict dualist states therefore, the rule reflects the idea that treaties are concluded by the Executive, while enactment of domestic law is a matter for the legislature. ${ }^{21}$

For these States, the distinction between self-executing and non-selfexecuting treaties describes a general attribute of treaties under their domestic law.

20 Nihal Jayawickrama, India, in THE Role of DOMEstic Courts IN TreAty ENFORCEMENT: A COMPARATIVE STUDY 326, 341-369 (David Sloss ed., 2009).

${ }^{21}$ Attorney General for Canada v. Attorney General for Ontario, [1937] AC 326 (PC) [347] (appeal taken from Can.). See generally CAMPBEll MCLACHLAn, Foreign Relations LAw 31, 81 (2014). Although these states can be described as "strict dualist" states with respect to treaties, we note that these same states are monist with respect to customary international law, which they regard as part of the law of the land without the need for legislative implementation. 
The terms are not used to distinguish some treaty provisions from others, as they are in states where treaties generally have direct effect as domestic law. As noted, the U.S. Constitution gives "all" treaties the force of domestic law. And, in the Netherlands-where the distinction between self-executing and non-self-executing treaties has also taken root $^{22}$ - treaties have a higher status in the domestic legal order than other forms of domestic law. ${ }^{23}$ In states like the United States and the Netherlands, therefore, a treaty's "non-self-executing" character does not relate to its status as domestic law, but rather describes a treaty that - while having the force of domestic law-is not directly applicable in the courts (either in all cases or in a given case).

As noted, one type of U.S. non-self-executing treaty purports to accomplish what, under the U.S. Constitution, may only be done by the legislature. The need to enact legislation to implement such treaties results from the Constitution itself, which disables the treaty-makers from accomplishing certain things directly. In light of the constitutional disability, treaties falling within this category of non-selfexecution might be thought to lack domestic legal force by virtue of the Constitution itself. Treaties in states that follow the British rule are "non-selfexecuting" in exactly this sense. The difference is that, in the United States, this category includes very few treaties, whereas in states following the British rule, this category includes all treaties.

South Africa presents a hybrid situation. It has departed from the British rule, but its constitution appears to provide that all non-self-executing treaties lack domestic legal force. Section 231(2) provides that some treaties "bind[] the Republic only after [they have] been approved by resolution in both the National Assembly and the National Council of Provinces." 24 Section 231(4) goes on to provide that "a self-executing provision of an agreement that has been approved by Parliament is law in the Republic unless it is inconsistent with the Constitution or an Act of Parliament." 25 A non-self-executing provision therefore does not have the force of domestic law (i.e., is not "law within the Republic"). South Africa thus employs the concept of self-execution to describe an attribute that some treaties possess and others lack, like the United States and the Netherlands but unlike strict dualist states (which use non-self-execution to describe all treaties in their legal systems). Unlike the United States and the Netherlands, however, the non-selfexecuting character of South African treaties always deprives them of domestic legal force.

Interestingly, states that do give treaties the force of domestic law have not followed the U.S. example of considering some treaties non-self-executing on the

${ }^{22}$ See Jan G. Brouwer, The Netherlands, in National Treaty LaW AND Practice 502505 (Duncan B. Hollis et al. eds., 2005).

${ }^{23}$ See id. at 498 ("the priority of treaty law over municipal law has never been seriously contested in the Dutch legal literature.").

${ }^{24}$ S. AFr. CONST., 1996 § 231(2).

${ }^{25} I d . \S 231(4)$. 
ground that they purport to accomplish something that, under their constitutions, may only be accomplished by law-makers. This is likely because these states generally require legislative consent before a treaty's ratification, and thus the treaty-makers and the law-makers are the same entities. ${ }^{26}$ Even in these states, however, the particular type of treaty obligation involved may, for constitutional reasons, impose additional constraints on the treaty provision's self-executing nature. For example, treaties that contemplate the criminalization of conduct will, in most states, require additional levels of specificity and clarity. ${ }^{27}$

\section{Non-Constitutional Non-Self-Execution}

In states that generally give domestic legal force to treaties, the term "nonself-executing" (and its cognate "no direct effect") describe an attribute of certain treaties, describing treaties that are not judicially enforceable in the absence of implementing legislation even though treaties generally have the force of domestic law. In some states, the distinction has its basis in explicit constitutional text. Thus, in the Netherlands, a constitutional amendment in 1956 clarified that "the power of courts [was] restricted to treaties that are self-executing." 28 The constitution provided that "[s]tatutory regulations ... . [may not be applied] . . . if such application is in conflict with [treaty] provisions ... that are binding on all persons." 29 The reference to treaties that are "binding on all persons" is generally understood to establish that the judicial power is limited to enforcing treaties that are self-executing. ${ }^{30}$ In most states that generally give treaties domestic legal force, however, courts have elaborated a similar distinction without constitutional text.

Courts applying the self-executing/non-self-executing distinction in these states appear to use it for issues similar to those addressed by the U.S. doctrine. One notable difference, however, is that non-U.S. courts rarely say that a treaty's self-executing character is a matter of intent. ${ }^{31}$ This could be because these courts recognize that treaties rarely-if ever-address whether they are to be enforced directly by courts or through implementing legislation. Indeed, recognition of this fact may explain why the Fourth Restatement takes the position that self-execution turns on the U.S. treaty-makers' intent or understanding rather than the intent of all

${ }^{26}$ See Duncan B. Hollis, A Comparative Approach to Treaty Law \& Practice, in NATIONAL TREATY LAW AND PRACTICE, supra note 22, at 36, 41.

${ }^{27}$ See, e.g., André Nollkaemper, The Netherlands, in The Role OF DOMESTIC CourTS IN Treaty Enforcement, supra note 20, at 357-58; Lech Garlicki et al., Poland, in The Role OF DOMESTIC COURTS IN TREATY ENFORCEMENT, supra note 20, at 370, 403.

${ }^{28}$ Brouwer, supra note 22, at 502-03.

${ }^{29}$ Id. at 503 (quoting The Netherlands' Constitution, art. 94).

${ }^{30}$ Id. (citing Kemerstukken II, 1955-1956 4133 (R 19), No. 3, 5) (“The term 'self-executing treaty provision' was considered to be a synonym [for the constitutional language].”).

31 There are isolated exceptions, however. See Nollkaemper, The Netherlands, supra note 27, at 341 (citing Supreme Court, E.O. v. Public Prosecutor, 18 April 1995, 28 N.Y.I.L. 1997, 336). 
parties. $^{32}$ In contrast, courts and commentators in other states have not taken the position that the self-executing nature of treaties turns on either the parties' intent or the unilateral intent of a given country's treaty-makers.

On the other hand, several non-U.S. courts echo the U.S. category of using self-execution to assess "whether the provision was designed to have immediate effect, as opposed to contemplating additional measures by the [legislature]." ${ }^{\prime 3}$ The Supreme Court of Poland, for example, has written that treaty provisions may be " "qualified as self-executing", when they "creat[e] immediate entitlements for citizens." "34 It has also found a treaty provision to be non-self-executing because "[ $\mathrm{t}]$ he wording of that provision indicates that it was directly addressed only to the State, establishing its obligation to adopt a corresponding penal norm." 35

Like U.S. courts, other states' courts sometimes use self-execution to refer to treaties that confer remedies on private parties. Thus, the Supreme Court of Poland has stated that "international agreement provisions are effective not only with regard to the States, but may provide an independent ground of claims for damages raised before domestic courts (so-called self-executing norms)." 36

By far the most common approach to self-execution for states that generally give treaties the force of domestic law is to regard treaties as self-executing when they are framed in sufficiently precise and obligatory terms for judicial application. Belgian legal scholar Marc Bossuyt describes this as the requirement that the treaty be "self-sufficient." 37 Judicial decisions from numerous states reflect this theme. Thus, Brouwer concludes that, "[e]xamining the [Netherlands Supreme] Court's case law, one may say that [a treaty will be deemed non-self-executing] if there is a lack of judicially manageable standards for resolving the question, or when the issue involved ought to be resolved by the legislator." 38 The Supreme Court of Poland has held that whether "a treaty may be regarded as self-executing" turns on

32 ReSTATEMENT (FourTh) $§ 110 \mathrm{cmt}$. c (“[T]reaties . . typically do not address the issue of domestic implementation."); id. $§ 110$ (2) ("Courts will evaluate whether the text and context of the provision are consistent with an understanding by the U.S. treatymakers that the provision would be directly enforceable in U.S. courts."). For a critique of the Restatement's emphasis on U.S. treaty-maker's intent, see Carlos Manuel Vázquez, Four Problems with the Draft Restatement's Treatment of Treaty Self-Execution, 2015 BYU L. Rev. 1747, 1761 (2015).

33 Restatement (Fourth) $§ 110(2)$.

${ }^{34}$ Garlicki et al., supra note 27, at 370, 402 (quoting I KZP 37/96, OSNKW 1997 nr 3-4, item 21). The court also suggested the provision must be "apt to be applied by the State bodies, especially by the courts and administrative organs," an apparent reference to the requirement, discussed below, that treaties be sufficiently precise and obligatory. Id.

${ }^{35}$ Id. at 403 (quoting V KKN 353/00, Lex 56863).

${ }^{36}$ Id. at 402 (quoting I CK 323/02, OSNC $2004 \mathrm{nr}$ 6, item 103).

37 See Marc Bossuyt, international Human Rights Protection: Balanced, CRITICAL, REALISTIC 104 (2016).

${ }^{38}$ Brouwer, supra note 22, at 504-05; Nollkaemper, The Netherlands, supra note 27, at 341 (reading the Dutch cases to establish that "a [treaty] provision can be applied [by the courts] only if it sufficiently clear from its content that it can serve as objective law"). 
"the completeness of the treaty provision that enables its operation without any additional implementation [in domestic legislation]." 39 The Hungarian Constitutional Court has stated that " $[\mathrm{t}]$ he precondition for applicability [of a treaty in domestic courts] is that those subject to the international treaty are precisely defined private entities and that the rights and obligations included in the treaty are specific enough so that the treaty is enforceable without any further domestic legislative action."40 And the Swiss Federal Supreme Court held a treaty (the Lisbon Treaty) was "not self-executing," while noting that "[a]ccording to the relevant case law, a treaty norm is directly applicable if its content is sufficiently precise and clear to form the basis of a decision in a particular case." 41 In other words, "[t]he norm . . . has to be justiciable ..."42

These cases do not explain the rationale for why insufficiently precise treaty provisions require legislative implementation. Bossuyt takes the position that a treaty's self-sufficient status "is a matter of international law." 43 The better vview, we think, is that sufficiency issues are a matter of domestic-rather than international-law. A provision that may be too vague to be directly enforced in the courts of one state may well be enforceable in another. In a number of Latin American states, for example, there is a "constitutional block" - i.e., specific human rights treaties designated for direct effect by the constitution or a constitutional court. $^{44}$ For example, Article 75 of the Argentine Constitution lists treatiesincluding the Covenant on Economic, Social and Cultural rights - as having a constitutional footing. ${ }^{45}$ As a result, the Argentine Supreme National Court has found provisions of the Covenant to be enforceable in Argentine courts. ${ }^{46}$ In contrast, other states like Switzerland view the same treaty's provisions as non-selfexecuting. ${ }^{47}$ In our view, neither the Argentine nor Swiss approach violates the

${ }^{39}$ Garlicki et al., supra note 27, at 402 (quoting I CK 323/02, OSNC $2004 \mathrm{nr} 6$, item 103). See also id. at 401-02 (noting that treaties are self-executing if they are "apt to be applied by the State bodies, especially by the courts and administrative organs").

40 Alkotmánybíróság (AB) [Constitutional Court] Mar. 29, 2005, 964/A/2004, Decision No. 7/2005 (III. 31) (Hung.). [Preventive Review of Unconstitutionality of Statute, Determination of Unconstitutional Omission to Legislate].

${ }^{41}$ Bundesgericht [BGer] [Federal Supreme Court] Mar. 13, 2014, 2C_457/2013 (Switz.). [X v. University of Lucerne, Student Administration Office and Department of Education and Culture of the Canton of Lucerne].

${ }^{42}$ Id.; see also Liechtenstein, Addendum, Report of the Working Group on the Universal Periodic Review, U.N. Doc. A/HRC/23/14/Add.1 $\$ 24$ (28 May 2013).

${ }^{43}$ BossuYt, supra note 37 , at 105.

${ }^{44}$ See Rene Urueña, Domestic Application of International Law in Latin America, Chapter $\mathrm{X}$, infra.

${ }^{45}$ Constitution of Argentina 1853 (reinst. 1983, rev. 1994), art. 75(22), English Trans. at https:/www.constituteproject.org/constitution/Argentina 1994?lang=en.

${ }^{46}$ Corte Suprema de Justicia de la Nación [CSJN] [National Supreme Court of Justice], 24/04/2012, "SYQC v. Government of the City of Buenos Aires/review of facts motion before the Supreme Court," (Arg.).

47 Cf. Bundesgericht [BGer] [Federal Supreme Court] Sept. 22, 2000, 2P.273/1999 (Switz.)[A and B v. Government of the Canton of Zurich]. 
requirements of the Covenant. If the treaty is consistent with a constitutional rule requiring implementing legislation in all circumstances, then it must also be consistent with an approach requiring implementing legislation because a state regards the treaty as too vague for direct judicial enforcement.

Nollkaemper offers a different rationale for the unenforceability of treaty provisions that are insufficiently clear or specific:

The principal basis for the requirement that the content of a treaty provision must be clear for it to have direct effect lies in the boundaries of judicial competence. If a court were to enforce a treaty provision that is formulated too openly, it would effectively be taking over the task of the legislature. ${ }^{48}$

This rationale seems to us to accord more closely to the language of the non-U.S. cases. And, as discussed above, it also may be the best explanation for the judicial unenforceability of vague/aspirational treaty provisions in U.S. courts. Indeed, the Dutch cases specifically invoke the absence of "judicially manageable standards" as the reason for finding a treaty provision non-self-executing, while the Swiss courts invoke the concept of justiciability. The phrase "judicially manageable standards" comes directly from Baker v. Carr, ${ }^{49}$ the leading case in the United States for the political question doctrine, which is a key justiciability doctrine. As one of us has argued, the notion that vague or aspirational treaty provisions are nonself-executing is best understood as the treaty-law equivalent of the political question doctrine.$^{50}$ Thus, these references to judicially manageable standards and justiciability are suggestive of the U.S roots of the "self-execution" doctrine in at least some states. ${ }^{51}$

\section{SELF-EXECUTION AS “FOREIGN" FOREIGN RELATIONS LAW?}

It is not surprising that the distinction between self-executing and non-selfexecuting treaties first emerged in the United States. The United States was the first country to adopt a Constitution giving treaties automatic force as domestic law. ${ }^{52}$ Its courts were thus among the first to determine whether that designation required judicial enforcement of all treaties, or, instead, permitted a judicial doctrine limiting enforcement to specific types of treaties.

48 Nollkaemper, The Netherlands, supra note 27, at 342.

49 See Baker v. Carr, 369 U.S. 186 (1962) ("Prominent on the surface of any case held to involve a political question is... a lack of judicially discoverable and manageable standards for resolving it.").

50 Vázquez, supra note 6 , at 715-16.

${ }^{51}$ Like self-execution, moreover, the migration of the political question doctrine across legal systems could itself be another example of FFRL.

52 See Ware v. Hylton, 3 U.S. (3 Dall.) 199, 277 (1796) (Iredell, J., dissenting) (U.S. Constitution "affords the first instance of any government . . . saying, treaties should be the supreme law of the land." (emphasis in original)). 
But how did other states come to self-execution? Did they import the term (and the underlying concept) from the U.S. legal system? This is the central question that motivates our inquiry into "foreign" foreign relations law (FFRL). Time and space make a definitive response difficult, but we offer here three framing questions on the (a) identification; (b) causation; and (c) evolution of self-execution as FFRL. We believe that these questions may be generalized across comparative foreign relations law to improve our descriptive (and perhaps normative) understanding of the field.

\section{Identification - What Constitutes FFRL?}

First, the concept of FFRL involves identification - asking if a particular term (or rule, or allocation of authority) in foreign relations law has external origins. In some cases, that lineage is clear. As noted, South Africa's Constitution explicitly references "self-executing treaties," and Botha notes that it "was taken over . . . from United States' jurisprudence." "53 In other cases identifying FFRLs will not be so easy. One problem lies in identifying what is being imported - is it just terminology, functions, or both? The British rule, for example, pre-dates the selfexecution concept. Thus, the use of "non-self-executing treaties" in that context was - at least initially - the mere importation of the term; it did not include the original distinguishing function that motivated self-execution's creation.

Identification may also be problematic in cases of functional convergence, where states use different terminology. One might find that the evidence supports reading such cases as FFRL, or, there may be instances where states, facing similar issues, reached the same solution independently. For example, even if the Netherlands' category of treaties with "direct effect" functions akin to selfexecuting treaties, further research is required to determine what - if any-role the U.S. doctrine of self-execution had in motivating the 1956 constitutional amendment that introduced that category.

Our comparative analysis of self-execution suggests, moreover, that FFRL may occur not just in whole, but also in part - some states appear to be adopting one particular thread of the U.S. self-execution concept without adopting all of them. Thus, Poland and Hungary have incorporated non-self-executing treaties involving vague or precatory terms without importing the idea of non-selfexecution based on party intent or constitutional delegation to other branches of the government.

FFRL may even be pluralist. The South African Constitution, for example, was subject to multiple foreign influences, including from the U.S., Canada, and Europe. ${ }^{54}$ It is possible that the introduction of self-executing treaties owed its

${ }^{53}$ See, e.g., Botha, supra note 3, at 91 (criticizing this borrowing)

${ }^{54}$ See, e.g., Dennis M. Davis, Constitutional Borrowing: The Influence of Legal Culture and Local History in the Reconstitution of Comparative Influence: The South African Experience, 1 INT'L J. CONST. L. 181, 187 (2003) (discussing American, Canadian, and German influences). 
origin not just to the U.S. jurisprudence, as Botha suggests, but also to European conceptions of self-executing treaties. Indeed, Michèle E. Olivier (who participated in drafting South Africa's earlier, Interim Constitution) suggests the current constitutional reference should be understood not only in light of U.S. doctrine, but also of E.U. experiences with self-execution. ${ }^{55}$ In other words, FFRL might be constructed from multiple foreign sources rather than just one. ${ }^{56}$

This last point is worth emphasizing. Although self-execution's origins may trace back to the United States, not all instances of FFRL will do so. For example, domestic authority to forego legislative approval of "executive agreements" has long been associated with U.S. foreign relations law. ${ }^{57}$ But it also appears in other states. It is not clear if modern iterations of executive agreements derived from the U.S. experience or sprung up elsewhere out of functional necessity or expediency. ${ }^{58}$ In other instances, U.S. foreign relations law concepts (e.g., the practice of concluding treaties among government agencies or ministries) appeared alongside similar practices elsewhere with no established time-line as to which state(s) originated the concept. ${ }^{59}$ There are, of course, numerous examples where FFRL is not associated with U.S. foreign relations law. For example, the British practice of concluding legally non-binding memorandum of understanding (MOUs) has been adopted in numerous other states, including many outside the Commonwealth. ${ }^{60}$

How then can we identify FFRL? More research could certainly do so, although it may be challenging. Differing languages will pose problems. Most states that give treaties domestic legal force are not English-speaking (most English-speaking states follow the British rule). Still, if foreign states' courts cite U.S. cases on self-execution, that would attribute to its domestic incarnation the character of FFRL. Of course, certain foreign legal systems (e.g., those that track

55 Olivier, supra note 4, at 118 (criticizing Botha's objections to self-execution in South Africa for "not taking cognisance . . . of the increasing body of academic discussion and judicial consideration of self-executing treaties within the context of the European Union").

${ }^{56}$ Of course, multiple foreign sources might all trace back to a single, original source (if, for example, EU versions of self-execution came from the U.S. concept) or multiple sources (if, for example, several states arrived independently at functionally similar — or even equivalentdistinctions for their treaties' domestic enforceability).

57 See, e.g., J. Mervyn Jones, Full Powers and Ratification 53-56 (1949); Francis O. Wilcox, The Ratification of International Conventions 226 (1935); SAmuel B. Crandall, Treaties, Their Making And EnForCement 102-140 (2d ed. 1916). 29.

${ }^{58}$ On the widespread use of executive agreements today, see Hollis, supra note 26, at 19-

59 See id. (surveying states that do - and do not-authorize inter-agency treaty-making); JONES, supra note 57, at 53-56 (noting practice of inter-departmental agreements).

${ }^{60}$ See, e.g., Anthony Aust, Modern Treaty Law And Practice, 26-28 (3 ${ }^{\text {rd }}$ ed., 2013); Duncan B. Hollis, Second Report on Binding and Non-Binding Agreements, Inter-American Juridical Committee, 92 ${ }^{\text {nd }}$ Regular Session, OAS/Ser.Q, CJI/doc.542.17 (Feb. 25-March 2, 2018) (Colombia, the Dominican Republic, Jamaica, Peru, and Uruguay report using MOUs to conclude non-binding agreements). 
the civil law) often cite sources less frequently than common law opinions. In such cases, references to "foreign" foreign relations scholarship by legislators, government officials, or scholars may provide an alternative vehicle for identifying FFRL. ${ }^{61}$

Nor is FFRL work limited to tracing the path of ideas; the movement of people (e.g., graduate study in U.S. law schools by foreign decision-makers) could assign FFRL status to a rule. ${ }^{62}$ In some cases, historical and cultural materials may identify FFRL patterns. For example, the shared history of France and Mexico could explain why both States authorize the conclusion of inter-institutional agreements (or what the French arrangements administratifs) that —unlike almost all other states - are viewed as only binding on the concluding agency and not the state as a whole. ${ }^{63}$ More rigorous methods for investigating FFRL would engage in process tracing or elite-level interviews. ${ }^{64}$

Identification studies might even include a search for cases of FFRL failure. We predict that sometimes research will reveal de minimis foreign influence on a state's foreign relations law. In other cases, a state's legal system may reject an invitation to adopt FFRL. In 2017, for example, the Supreme Court of Ghana was invited to adopt the U.S. concept of executive agreements to legitimate a bilateral treaty with the United States resettling two detainees from the Guantanamo naval base. The Court refused to endorse the executive agreements category, holding instead that all Ghanaian treaties require parliamentary approval. As a result, the Court ruled that the treaty was unconstitutional. ${ }^{65}$

\section{Causation - Why do States Import Self-Execution?}

61 For example, Olivier's analysis of self-execution in South Africa shows a deep familiarity with U.S. and European scholarship on self-execution. See Olivier, supra note 4, at 100 n.4 (citing scholarship).

62 See Vicki Jackson, Comparative Constitutional Law: Methodologies, in MiCHAEL ROSENFELD AND ANDRÁS SAJÓ, EDS., THE OXFORD HANDBOOK OF COMPARATIVE CONSTITUTIONAL LAW 58 (2012). Anthea Roberts' studies of difference and dominance in international law similarly emphasizes the role of academics and textbooks. See COMPARATIVE InTERnATIONAL LAw, supra note 1 , chs. 3 and 4 .

${ }^{63}$ Compare Pierre Eisemann \& Raphaële Rivier, France, in NATIONAL TREATY LAW AND PRACTICE, supra note 22, at 253, 255 (describing arrangements administratifs concluded by French governmental agencies and their counterparts which "do not bind the State, only the signatory agency"); with Law Regarding The Making Of Treaties, reprinted in 31 ILM 390 (1992), CDLX Diario Oficial de la Federación 2 (Jan. 2, 1992); Luis Miguel Diaz, Mexico, in NATIONAL TREATY LAW AND PRACTICE, supra note 22, at 450 (under its treaty law, Mexico's inter-institutional agreements are "only binding upon those agencies which have entered into them, and not upon the federation").

64 See, e.g., Jackson, supra note 62, at 58-60 (surveying historical and migration methodologies and scholarship in comparative constitutional law).

65 See Banful v. Attorney General, J1/7/2016 [2017] GHASC 10 (June 22, 2017). The Ghanian legislature subsequently approved the agreement. For a similar judicial approach in the Dominican Republic see Judgement of Plenary of the Supreme Court of Justice, Aug. 10, 2005, B.J. 1037 (Dom. Rep.). 
Assuming that we can identify self-execution or other examples as FFRL, the next question is what caused the State to import it? Why do states incorporate foreign rules, doctrines, or allocations of authority within their foreign relations laws? We envision at least four possible causes for FFRL: (i) function; (ii) bricolage; (iii) power; and (iv) socialization.

First, FFRLs may arise due to their functional appeal. With globalization, states increasingly must mediate the relationship between their internal law and international legal obligations. In doing so, they encounter new issues for which their internal law has yet to offer an answer. In such cases, the state's decisionmakers may survey solutions elsewhere and find one (or more) they believe will work best for their situation. Our survey above suggests that, in many states, the distinction between self-executing and non-self-executing treaties covers a wide range of reasons for why a treaty is not subject to judicial application. The attraction to judges of having discretion to enforce a treaty (or not) is one plausible explanation for the spread of the amorphous doctrine of self-execution among states that have (or, like South Africa, have shifted to) a system in which treaties have the status of domestic law. ${ }^{66}$

Second, FFRL may be the product of what Mark Tushnet identifies as bricolage. ${ }^{67}$ Bricolage would explain the advent of FFRL as the result of happenstance rather than carefully calibrated functional analysis, where decisionmakers simply adopt concepts about which they have some awareness. To the extent the United States has the most robust (and certainly most written about) foreign relations law, its concepts may be the most likely candidates for FFRL. ${ }^{68}$ Thus, an alternative explanation for self-execution's global diffusion may be its visibility rather than its utility. Bricolage may explain why states adopted the terminology of self-execution rather than one or more of the four (more coherent) threads it contains.

Power offers a third - and very different - rationale for the existence of FFRL. Power can manifest itself in various efforts to impose FFRL on a targeted state. In some cases, international institutions might mandate the direct application of treaties. Thus, the European Court of Justice (ECJ) has held that certain treaty provisions and acts of EU institutions have "direct effect" in member states' legal

${ }^{66}$ Alternatively, courts might find functional appeal in self-execution as a way to respect separation of powers, leaving to legislatures the implementation of vague/aspirational treaty provisions.

67 Tushnet, supra note 1 , at 1286.

${ }^{68}$ It would be interesting to assess by which networks FFRLs move. As a technical concept, self-execution would most likely migrate via inter-governmental networks of officials or academics. See, e.g., AnNe Marie Slaughter, A New World Order (2004). In contrast, for FFRLs addressing fundamental values (e.g., human rights), Linos' policy diffusion theory suggests patterns of movement originating from "large, rich, and culturally proximate countries." KATERINA Linos, The Democratic Foundations of Policy Diffusion 5 (2013). 
orders. ${ }^{69}$ And the Inter-American Court of Human Rights (IACtHR) insists that member states directly apply the American Convention on Human Rights - and the Court's interpretation of it-within their internal legal orders. ${ }^{70}$ In other cases, power dynamics might be internal to the state - the result of interactions among executives, courts, and legislatures.

Power dynamics may also be less formal, resulting from spheres of influence or the long tail of colonialism. That Commonwealth states follow the "British rule" is a function of those states' historical relationship with the United Kingdom. ${ }^{71}$ A similar rationale could explain the use of MOUs among Commonwealth states. But, power also has limits; states can reject the attempted imposition of a rule. For example, states outside the British sphere (most notably the United States) have not adopted the linguistic cues or architectural artifacts of MOUs in concluding political commitments. ${ }^{72}$ We have our doubts, moreover, that the spread of the self-execution doctrine resulted from power dynamics; we would need to see further evidence of U.S. interests favoring the bifurcation of other states' judicial enforcement of treaties.

Fourth, forces of socialization may motivate the creation of FFRL. Some FFRL is likely the result of mimicry. Social scientists have long known that states sometimes conform their systems to those of other states who they perceive as successful. The calculation can be instrumental (i.e., "we'll do what they do to get where they are") or affective (i.e., "to be regarded as responsible, we should do this too"). ${ }^{73}$ Under this view, self-execution might be adopted-as a term or conceptto mimic the U.S. doctrine.

Alternatively, FFRL may emerge for expressive purposes. A state might adopt a regime not because of its functions, but because of what it signals to other states about the nation and its identity. ${ }^{74}$ For example, South Africa may have adopted the concept of self-executing treaties as much to signal its commitment to human rights and their enforcement as to making functional distinctions among treaties based such factors as precision. ${ }^{75}$ Rene Urueña's chapter in this volume provides another example, examining how Latin American states may forgo the

${ }^{69}$ See Case C-26/62, Van Gend en Loos, 1963 E.C.R. 1, 13.

70 See Urueña, supra note 44 (recounting direct effect for IACHR opinions under the heading "conventionality" in Brazil, Bolivia, Honduras, Mexico and Peru, while noting resistance to doing so in Argentina, Chile, the Dominican Republic, and Venezuela).

${ }^{71}$ Of course, some former colonies (e.g., the United States, South Africa) rejected or varied the British rule, suggesting inertia may be at work alongside power dynamics.

72 See Aust, supra note 60, at 38-39.

73 See, e.g., Paul DiMaggio \& Walter W. Powell, The iron cage revisited: Collective rationality and institutional isomorphism in organizational fields, 48 AM. SocIO. REV. 147, 151 (1983)

74 See, e.g., Jackson, supra note 62, at 66-67 (surveying expressivim in scholarship).

75 See, e.g., Olivier, supra note 4, at 119 (emphasizing self-execution's role in advancing human rights). 
very concept of foreign relations law because it is alien to their understanding of international law as something not outside, but inside, their internal law. ${ }^{76}$

These four causes should not be understood as exhaustive. Nor do we mean to suggest they will arise in isolation; FFRL may have not one, but perhaps multiple, causes. The spread of self-execution, for example, may be explained in functional terms and as the product of mimicry or bricolage. Other FFRLs might result from different menus of causal factors.

Moreover, FFRLs could conceivably have different causes at different times. Self-execution might have originally spread for reasons of bricolage or mimicry. But it might be sustained within a system for functional reasons whether in terms of judicial discretion or separation of powers. ${ }^{77}$ Similarly, the use of nonbinding MOUs might have been originally imposed by a metropolitan power, but other causes (perhaps the functional utility of coordinating non-binding commitments around a common format) may explain their subsequent spread beyond the Commonwealth.

\section{Evolution - How Does FFRL Evolve Over Time?}

Even after identifying FFRL and examining why it occurs, the story of its evolution remains. To begin, we should compare the similarities and differences of the FFRL to its original source. While self-execution in some states appears to track some of the features of the U.S. doctrine, some states do not appear to have adopted all the concepts subsumed under the U.S. self-executing heading. Differences in form may also prove significant. Consider, for example, selfexecution's shift in South Africa and the Netherlands from a judicially-developed doctrine to one specified in constitutional text. Doing so may affect the doctrine's status within the domestic legal order and, more importantly, trigger a different set of interpretative methodologies - i.e., those applicable to constitutions rather than judicial opinions.

Beyond comparing FFRL manifestations, we should also ask about their dynamic character. Does FFRL hew to its original boundaries or change over time? In the context of self-execution, the appeal to judges of the U.S. doctrine's malleability - evidenced by its amalgamation of a variety of distinct reasons why a treaty might not be judicially enforceable — suggest that it is unlikely to evolve (at least overtly) to any great extent. On the other hand, frustration among judges and scholars with the doctrine's indeterminacy may produce pressures for clarification.

Then there is the question of how the FFRL affects the state's foreign relations law more generally. Following the British rule, for example, implicates a

\footnotetext{
${ }^{76}$ Urueña, supra note 44, at 16.

${ }^{77}$ In South Africa, in contrast, the self-execution concept has rarely been employed, suggesting its utility has not been perceived as greater than obtaining parliamentary implementation for South Africa's treaties.
} 
whole set of rules and allocations of authority (e.g., the plenary power of the executive in treaty-making). Similarly, as we have explained, self-execution implicates not only how international legal obligations enter the domestic legal system, but it also has broader implications for the separation of powers between a state's judiciary and legislature.

One might even ask about the impact of FFRL outside of the state in which it emerges. As FFRL evolves, it might become a source on which other states rely. To the extent that one instance of FFRL creates another, FFRL can operate as much as the influencer as the influenced. Indeed, it might even be possible for certain strains of FFRL to create a feed-back loop influencing the evolution of the original rule or regime. To date, self-execution has not exhibited such a pattern - for the most part, U.S. self-execution doctrine still looks only to U.S. precedents. But there may be much for U.S. courts and scholars to learn from how this (possibly) transplanted doctrine has fared abroad. More generally, the experience of other states with FFRL might cause the originating state to rethink its own foreign relations law.

\section{CONCLUSION}

In 1829, the U.S. Supreme Court introduced the idea that, despite the constitution designating all U.S. treaties the "law of the land," U.S. courts would only enforce those treaties labeled as "self-executing." "78 In the $20^{\text {th }}$ century, this distinction evolved to identify different types of unenforceable U.S. treaties. Today, this concept of self-execution and the various doctrines it contains are no longer a uniquely U.S. feature (or as some suggest, a bug) of its foreign relations law. Various manifestations of self-execution - either in name, function, or bothare visible in other states' internal legal systems.

In at least some of these cases, we find indications that states have derived their version of self-execution from U.S. jurisprudence (i.e., as FFRL). This chapter offered an introduction to the FFRL concept and suggested ways to examine it along three different lines of inquiry. First, we suggest that there is value merely in identifying those parts of a state's foreign relations law that have external origins (whether in whole or in part, and whether from single or multiple sources), including cases where a state rejects proposed FFRLs. Second, we ask what causes FFRLs, and offer four potential rationales: function, bricolage, power, and socialization. Third, and finally, we inquire into how FFRL converges or diverges from its source initially and over time, while evaluating FFRL's potential impact on the state's and other states' foreign relations law.

But why engage in this approach? What value can our inquiry have? Comparative law projects are usually celebrated for enhancing intellectual knowledge and improving self-reflection by increasing knowledge of other

${ }^{78}$ See Foster v. Nielson, 27 U.S. (2 Pet.) 253, 314 (1829). 
systems. ${ }^{79}$ Both goals are served by FFRL. Appreciating that foreign relations law's origins lie not only in a state's history and internal dynamics inevitably increases our understanding of what law "is" and how it changes. Moreover, for scholars of foreign relations law, looking at how these concepts travel creates new opportunities to evaluate the system within which they reside. Some U.S. scholars have found the self-execution doctrine to be confusing if not incoherent. By looking at how other states engage with self-execution, U.S. foreign relations lawyers can gain a new appreciation not only of specific categories of selfexecution, but their functional utility (especially when compared to foreign variations).

Understanding FFRL may also assist in mapping convergence and divergence across national systems. Our research suggests that - as a matter of national law — most states judicially enforce some — but not all — of their treaties. The more states come to accept this reality, the more they may be sensitized to (or perhaps even accepting of) another state court's reticence in empowering its courts to enforce particular types of treaty provisions without additional guidance from the legislature. Conversely, where we see states rejecting FFRL, it may signal areas at risk for future tensions or conflict. Rejecting the idea of executive agreements in Ghana, for example, threatened the underlying agreement's validity and the goals motivating that deal. The U.S. refusal to import the Commonwealth MOU practice produced some significant disputes over the legal status of certain defense MOUs it concluded with those states. ${ }^{80}$

FFRL may even have normative value. Certain rationales for adopting FFRL have greater normative purchase than others. Functionally motivated FFRLs may be desirable, while FFRLs that result from power dynamics, especially those with a colonial heritage, are more undesirable. In other words, a better understanding of FFRL may allow states to be more conscious in their choices of whether and when to import/export foreign relations laws.

Finally, FFRL may improve the normative appeal of comparative foreign relations law itself. At present, the field risks U.S. exceptionalism-not in the sense of distinguishing foreign relations law from other rules for internal law-but in pushing states to conceptualize their internal law along U.S. lines. ${ }^{81}$ Our inquiry offers a more transparent approach to understanding where ideas and approaches originate and how they move across boundaries. In doing so, it offers the promise of a truly global field rather than one indexed to U.S. versions of ideas like selfexecution.

\footnotetext{
79 Jackson, supra note 62, at 70-72.

80 See, e.g., John H. McNeill, International Agreements: Recent U.S.-U.K. Practice Concerning the Memorandum of Understanding, 88 AM. J. INT'L L. 821 (1994).

${ }^{81}$ Accord Karen Knop, Foreign Relations Law: Comparison as Invention, Chapter X, infra.
} 